\title{
Epistemologi Islam Dalam Tinjauan Filosofis
}

\author{
Ummi Kulsum \\ ummikulsumelsyifa85@gmail.com \\ STIT Aqidah Usymuni Sumenep
}

\begin{abstract}
:
Branch epistemology is from the scientific discipline of knowledge that discusses its nature, scope, and limitations. This study is a means of solving a fundamental question. In Islamic thought, there are three epistemological structures, namely Bayani, Irfani, dan Burhani. Bayani epistemology, is defined as athought that emphasizes the authority of the texs (nas), which means understanding the texs as knowledge without any interpretation. While the epistemology of Irfani is called presented knowledge (hudluri Science). This epistemology is developed and used in sufi society. While epistemology Burhani, can be defined as an activity to realize the truth of a proposition (qadhiyah ) through a deductive approach developed by many philosophical figures.
\end{abstract}

Keyword, Epistemologi, Islam, dan Filosofis

\section{PENDAHULUAN}

Epistemologi sering juga disebut dengan teori pengetahuan (theoryofknowledge). Secara etemologi, epistemologi merupakan gabungan dari dua kata yang berasal dari bahasa Yunani: episteme dan logos. Episteme artinya pengetahuan, logos biasa digunakan untuk menunjukkan adanya pengetahuan sisitematik. Dengan ini, epistemologi dapat diartikan sebagai pengetahuan sistematis mengenai pengetahuan. Epistemologi kadang disebut logika atau ilmu tentang berpikir.

Epistemologi adalah cabang dari disiplin ilmu filsafat mengenai pengetahuan yang membahas hakikat, ruang lingkup dan batasan-batasannya. Studi ini merupakan sarana dalam memecahkan suatu pertanyaan-pertanyaan mendasar seperti: Bagaimanakah sifat pengetahuan? Apakah yang merupakan pembatasan-pembatasan praktis dan teoritis ilmu pengetahuan? Dan seterusnya. Dalam hal ini, senada dengan pandanga Harun Nasution, menurutnya, 
epistemologi adalah ilmu yang membahas, apa itu pengetahuan dan bagaimana cara memperoleh pengetahuan itu. ${ }^{1}$

Menurut Harun Nasution, epistemology adalah ilmu yang membahas: apa itu pengetahuan dan bagaimana cara memperoleh pengetahuan itu. Pengetahuan pada hakikatnya adalah keadaan mental (mental state). ${ }^{2}$ Jadi, mengetahui sesuatu adalah Menyusun pendapat tentang sesuatu atau Menyusun gambaran dalam akal tentang fakta yang ada di luar akal. Pengetahuan selalu melibatkan relasi antara subjek dan objek. Ia selalu bersifat objektif-subjektif, subjektif-objektif.

Islam telah memberikan perhatian besar mengenai epistemologi, karena untuk memadukan antara pengetahuan dan ajaran wahyu, di satu pihak dengan pengetahuan dan ajaran manusiawi, intelektual-rasional di pihak lain seperti yang dilakukan oleh para filosof yang telah berusaha dan mengharmoniskan pengetahuan akal manusiawi-rasional dengan ajaran agama yang bersifat samawisupranatural. Namun, perpaduan tersebut selalu saja dilihat oleh masyarakat dengan ketidak percayaan dan kecurigaan.

Terlepas dari pro dan kontra dari pertumbuhan dan perkembangan logika Aristoteles di dunia Islam, dengan sikap yang optimistik, ia telah memberikan dampak yang besar dalam melahirkan dan mengembangkan beberapa aliran epistemologi dalam Islam. Pemikiran Aristoteles yang bercirikan pemikiran rasional telah melahirkan satu macam teologi kaum rasionalis dalam Islam, yang diwakili oleh kaum Mu'tazilah. ${ }^{3}$ Pada perkembangaanya, epestemologi Islam mencakup tiga struktur, yaitu epistemologi bayani, epistemologi irfani, dan epistemologi burhani. Tulisan ini akan memaparkan epistemologi Islam, yang meliputi sejarah dan perkembagannya dalam tinjauan filosofis.

\section{Pembahasan}

\section{Struktur Epistemologi Islam}

\section{Bayani}

Bayani dari kata bahasa Arab bayan atau penjelasan. Menurut al-Jabiri (19362010 M), bayan mempunyai arti al fashl wa infishal (memisahkan dan terpisah) dan al-dhuhur wa al idhhar (jelas dan penjelasan). Epistemologi Bayani bisa juga diartikan sebagai pemikiran yang menekankan otoritas teks (nash), artinya memahami teks sebagai pengetahuan tanpa ada penafsiran. Secara termenologi,

\footnotetext{
${ }^{1}$ Zainul Kamal, Ibn Taimiyah Versus Para Fiosof: Polemik Logika, (Jakarta: Raja Grafindo Persada, 2006), 203.

${ }^{2}$ Harun Nasution, Filsafat Agama, (Jakarta: Bulan Bintang, 1983), 14.

${ }^{3}$ Nasution, Filsafat..., 204
} 


\section{Umi Kulsum}

Epistimologi Islam Dalam Tinjauan Filosofis

bayan mempunyai dua arti, yaitu sebagai aturan-aturan penafsiran wacana dan syarat-syarat memproduksi wacana. ${ }^{4}$

Epistemologi ini dikembangkan kan dan digunakan oleh para fuqaha, mutakallimun dan ushuliyyun. Bayani adalah pendekatan untuk memahami atau menganalisis teks untuk menemukan makna yang dikandung dalam lafadz. Dengan itu, epistemologi bayani menggunakan instrumen berupa ilmuilmu bahasa dan uslub-uslubnya serta asbabun nuzul, dan istinbath atau istidlal sebgai metodenya. ${ }^{5}$

Menurut Khudori Soleh, sejarah epistemologi bayani ditandai dengan lahirnya kitab Al-Asybah wa al-Nazhair fil Qur'an al-Karim karya Muqatil ibn Sulaiman (719-763 M) dan Ma'ani al-Qur'an karya ibn Ziyad Al-Farra' (757$823 \mathrm{M}$ ) yang keduanya menjelaskan makna atas kata-kata dan ibarat-ibarat yang ada dalam al-Qur'an.

Pengertian tentang bayani tersebut kemudian berkembang sejalan dengan perkembangan pemikiran Islam. Begitu juga dengan aturan-aturan metode di dalamnya. Pada masa Al-Syafi'i (767-820 M) yang dianggap sebagai peletak yurisprudensi Islam, bayani berarti nama yang mencakup makna-makna yang mengandung persoalan ushul (pokok) dan yang berkembang hingga ke cabang (furu'). Sedangkan dari segi metodologi, Al-Syafi'i membagi bayan dalam lima bagian: Pertama, bayan yang tidak membutuhkan penjelasan lanjut, seperti yang dijelaskan dalam al-Qur'an yang mengandung makna qoth'i. Kedua, bayan yang beberapa bagiannya masih global (dhonni) sehingga butuh penjelasan sunnah. Ketiga, bayan yang keseluruhannya masih global sehingga butuh penjelasan sunnah. Keempat, bayan sunnah, sebagai uraian sesuatu yang tidak terdapat dalam al-Qur'an, dan Kelima, bayan ijtihad yang dilakukan dengan qiyas atas sesuatu yang tidak terdapat dalam al-Qur'an dan sunnah.

Sementara menurut Al-Jahizh (781-868 M), bayan adalah syarat-syarat untuk memproduksi wacana dan bukan sekedar aturan aturan penafsiran wacana. Jahizh menetapkan syarat bagi bayani: Pertama, syarat kefasihan ucapan, kedua, seleksi huruf dan lafal-lafal sehingga penyampaiannya tepat guna. Ketiga, makna harus bisa diungkapkan dengan salah satu dari lima bentuk penjelasan, yaitu lafal, isyarat, tulisan, keyakinan, dan nisbah, keempat, adanya kesesuaian antara kata dan makna, dan kelima, adanya kekuatan kalimat yang dapat diakui secara umum. Namun, apa yang ditetapkan Al-Jahizh pada masa berikutnya dianggap kurang tepat dan sistematis. ${ }^{6}$

\footnotetext{
${ }^{4}$ Khudori Soleh, Filsafat Islam; dari Klasik hingga kontemporer, (Jogjakarta: Arruzz Media, 2013 ), 237.

${ }_{5}$ Dalam epistemologi bayani, domenasi teks begitu kuat, maka peran akal hanya sebatas alat sebagai pembenaran atau justifikasi atas teks yang dipahami.

${ }^{6}$ Soleh, Filsafat Islam ..., 238.
} 
Menurut Ibn Wahhab Al-Khatib dan Al-Farabi (870-950), bayani bukan diarahkan untuk "mendidik" pendengar melainkan sebuah metode untuk membangan konsep di atas dasar ushul-furu', dengan menggunakan sistematika yang dipakai ulama'figh dan kalam (teologi). Ibn Wahhab menawarkan empat macam bayani: pertama, bayan al-i'tibar (untuk menjelaskan sesuatu yang berkaitan dengan materi). Kedua, bayan al-i'tiqad (berkaitan dengan hati), ketiga, bayan al-Ibarah (berkaitan dengan teks dan bahasa), keempat, bayan al-Kitab (berkaitan dengan konsep-konsep tertulis).

Pada periode terakhir muncul Al-Syathibi (1336-1388M), dari berbagai argumen di atas menurutnya, bayani belum bisa memberikan pengetahuan yang pasti (qath'i) tapi baru derajat (zhanni) sehingga tidak dapat dipertanggungjawabkan secara rasional. Karena itu, Syatibi menawarkan tiga teori untuk memperbaharui bayani. Pertama, al-istintaj (menarik kesimpulan berdasarkan dua premis yang mendahului), kedua, al-istiqra' (penelitian terhadap teks-teks yang setema kemudian diambil tema pokoknya) 'dan ketiga, maqashid al-Syar'i (tujuan-tujuan diturunkannya syari'at). Ketiga teori itu, telah dikembangkan dari pemikiran Ibn Hazm (994-1064 M) dan Ibn Rusyd (1126$1198 \mathrm{M}){ }^{7}$

\section{Irfani}

Epistemologi irfani adalah salah satu model penalaran yang dikenal dalam tradisi keilmuan Islam, di samping bayani dan burhani. Epistemologi ini dikembangkan dan digunakan dalam masyarakat sufi. ${ }^{8}$ Istilah irfan berasal dari kata dasar bahasa Arab 'arafa, ya'rifu irfan, sinonem dari kata ma'rifat, yang berarti pengetahuan, tetapi berbeda dengan ilmu. Irfan atau makrifat berkaitan dengan pengetahuan yang diperoleh secara langsung dari Tuhan (kasyf) lewat olah rohani yang dilakukan atas dasar cinta atau iradah atau kemauan yang kuat. Sedangkan ilmu menunjukkan pada pengetahuan yang diperoleh lewat transformasi (naql) atau rasionalitas $(a q l) .{ }^{9}$

Dalam literatur Barat Irfani dikenal dengan istilah gnosis. Dalam pandangan al-Junaid (w.381 H), Irfan dianggap sebagai hal, sedangkan dalam Risalah alQusyairiyah, Irfan dianggap sebagai maqam. Sementara itu, al-Ghazali dalam kitabnya Ihya' Ulum al-Din memandang Irfan dating sebelum mahabbah. Selanjutnya, ada pula yang mengatakan bahwa irfan dan mahabbah merupakan dua hal yang selalu disebut secara bersamaan. Keduanya menggambarkan kedekatan seorang sufi dengan Tuhan-Nya. Dengan kata lain, irfan dan

${ }^{7} \mathrm{Ibid}, 241$.

8Sirajuddin Zar, Filsafat Islam Filosof dan Filsafatnya, (Jakarta: Raja GrafindoPersada, 2012), 218.

9Ibid; 219. 
mahabbah menggambarkan dua aspek dari hubungan dekat yang ada antara seorang sufi dengan Tuhan. Dengan demikian, kelihatannya yang lebih dapat dipahami bahwa Irfan dating sesudah mahabbah sebagaimana dikemukakan alKalabazi. Hal ini disebabkan karena Irfan lebih mengacu kepada pengetahuan, sedangkan mahabbah menggambarkan kecintaan. ${ }^{10}$

Menurut Mehdi Hairi Yazid, pengetahuan irfan disebut sebagai "pengetahuan yang dihadirkan" (ilmu hudluri), berbeda dengan pengetahuan rasional yang disebut sebagai "pengetahuan yang dicari" (ilm muktasab). Dalam perspekti Henri Bergson, pengetahuan irfan diistilahkan dengan "pengetahuan tentang" (knowledge of) sebuah pengetahuan intuitif yang diperoleh secara langsung, berbeda dengan "pengetahuan mengenai" (knowledge about), yaitu pengetahuan yang diperoleh lewat perantara, baik indra atau rasio ${ }^{11}$.

Sementara Muthahhari (1920-1979 M), membagi irfan dengan dua aspek: teoritis dan praktis. Pada aspek teoritis, irfan mendiskusikan hakikat semesta, manusia, dan Tuhan sehingga irfan teoritis mempunyai kesamaan dengan filsafat yang juga mendiskusikan hakikat semesta. Meskipun demikian, irfan tetap tidak sama dengan filsafat dengan berbagai faktor, di antaranya adalah: pertama, filsafat medasarkan argumentasinya pada postulat-postulat atau aksioma-aksioma, sedangkan irfan mendasarkan pada visi dan intuisi. Kedua, dalam pandangan filsafat, eksistensi alam sama dengan eksistensi Tuhan. Sementara dalam pandangan irfan, eksistensi Tuhan meliputi segala sesuatu termasuk sifat-sifat-Nya.

Pada aspek praktis, irfan mendiskusikan hubungan antara manusia dengan alam dan hubungan antara manusia dan Tuhan. Misalnya, orang yang ingin mengenal Tuhan, maka yang harus dilakukan adalah dengan menempuh perjalanan spiritual lewat tahapan-tahapan tertentu dan kondisi-kondisi tertentu. Karena bagi kaum irfan, mengenal Tuhan berarti mengenal keesaannya. ${ }^{12}$

Selanjutnya, menurut Ibn Thufail Irfan itu dimulai dari panca indra. Dengan pengamatan dan pengalaman dapat diperoleh pengetahuan indrawi. Hal-hal yang bersifat metafisis dapat diketahui melalui intuisi. Irfan dapat diperoleh melalui latihan-latihan rohani dengan penuh kesungguhan. Semakin tinggi latihan, maka Irfan semakin jelas, dan berbagai hakikat akan tersingkap (kasyfuruhani). Hal ini merupakan ekstase yang tidak dapat dilukiskan dengan

10Ibid, 221.

11Al-Jabiri, bunyah al-aql al-arabi (beirut: al-markaz al-Tsaqafi al-Arabi, 1993), 253.

12 Khudori Soleh, Filsafat Islam, 254-255. 


\section{Umi Kulsum}

Epistimologi Islam Dalam Tinjauan Filosofis

kata-kata sebab kata-kata hanya merupakan simbol-simbol yang terbatas pada pengamatan indrawi. ${ }^{13}$

Secara umum, perkembangan irfani dibagi dalam lima periode. Periode pertama, yang disebut dengan "periode pembibitan", yaitu pada abad petama hijriyah. Pada periode ini dibuktikan dalam bentuk zuhud. Menurut Thabathaba'i (1892-1981 M), para tokoh irfan dikenal sebagai orang-orang suci, meskipun mereka tidak berbicara tentang irfan secara terbuka. Karakter ini berdasarkan ajaran al-Quran dan sunnah, yaitu menjauhi hal-hal duniawi demi mendapatkan pahala dan menjaga diri dari neraka.

Periode kedua, dikenal dengan "periode kelahiran" yang terjadi pada abad ke 2 hijriyah. Pada periode ini, beberapa tokoh mulai berbicara terbuka mengenai irfan. Karya-karya irfan juga mulai ditulis. Seperti karya Hasan Basri (642-728) Ri 'ayat Huquq Allah. Kemudian Mishbah al-Syari'ah karya Fudhail ibn Iyadh (721-803). Pada perkembangan selanjutnya, pengertian zuhud mulai berubah tidak lagi dilakukan atas dasar takut dan mengharap pahala, tetapi dilakukan atas dasar cinta kepada Tuhan. Pengertian ini yang dikembangkan oleh Rabiah Adawiyah (717-801 M).

Periode ketiga, atau "periode pertumbuhan" terjadi pada abad ke 3-4 hijriyah. Pada abad 3 ini para tokoh irfan mulai banyak yang tertarik dengan hal-hal yang berkaitan dengan jiwa dan prilaku, pada perkembangannya irfan menjadi ilmu moral dan keagamaan (akhlak), sehingga Pada pembahasan selanjutnya, para tokoh irfan mulai membahas tentang pengetahuan intuitif yang disertai dengan sarana dan metodenya.

Dengan demikian, pada periode ini, irfan telah mengkaji soal moralitas dan pengenalan intuitif langsung pada Tuhan, kefanaan dalam realitas mutlak, dan pencapaian kebahagiaan, disamping penggunaan simbol-simbol dalam pengungkapan hakikat realitas yang dicapai irfan, seperti yang dilakukan Dzun Al-Nun Al-Misri (796-861 M), kemudian dikembangkan oleh Junaid AlBaghdadi (830-910 M), dan disampaikan di atas mimbar secara terbuka oleh Abu Bakar Al-Syibli (861-946 M). ${ }^{14}$

Periode keempat, dikenal dengan "periode puncak", terjadi pada abad ke5 Hijriyah. Pada periode ini banyak tokoh yang lahir dan menulis tentang irfan, antara lain, Said Abu Khair (967-1048 M) dengan kitabnya Ruba'iyat, Ali Ibn Utsman Al-Hujwiri (990-1077 M) Kasyf al-Mahjub dan Abdullah Al-Anshari (1006-1088 M) menulis Manazil al-Sairin, dan salah satu terpenting tentang irfan.

13Sirajuddin Zar, Filsafat Islam Filosof dan Filsafatnya, 219.

14Ibid, 269 
pada puncaknya Al-Ghazali (1058-1111 M) menulis kitab Ihya' Ulumuddin, yang menyelaraskan antara tasawuf dan fiqh (irfan dan bayani). ${ }^{15}$

Periode kelima, atau "periode spisifikasi", terjadi pada abad ke-6 Hijriyah. Berkat pengaruh Al-Ghazali yang besar, irfan menjadi semakin dikenal dan berkembang di tengah-tengah masyarakat Islam. Sehingga banyak memberikan peluang kepada para tokoh sufi untuk mengembangkan tarekat-tarekan yang kemudian diajarkan kepada murid-muridnya, seperti yang dilakukan Abd AlQadir Al-Jailani (1077-1166 M), Ahmad Al-Rifa'i (1118-1181 M), Abu Hasan AlSyadzili (1196-1258 M), Abu Abbas Al-Mursi (1219-1286 M), dan Ibn Athaillah Al-Iskandari (1250-1309 M). ${ }^{16}$

Pada periode ini juga, ada beberapa tokoh yang mencoba mengkolaborasikan irfan dengan filsafat, seperti Suhrawardi (1153-1191 M) dengan karyanya Hikmah al-Isyraq. Umar Ibn Faridh (1181-1235 M), dan Ibn Arabi (1165-1240 M), bahkan pada periode ini, Suhrawardi dan Ibn Arabi telah mempelopori penulisan pengalaman mistiknya yang dikenal dengan "pengetahuan irfan". Dengan demikian, pada periode ini, secara epistemologis irfan sudah menjadi dua aliran. Pertama, "irfan sunni" yang cendrung pada perilaku praktis (etika) dalam bentuk tarekat-tarekat. Kedua, "irfan teoritis" yang didominasi oleh pemikiran filsafat. ${ }^{17}$

Periode keenam, atau "periode kemunduran" terjadi pada abad ke-8 Hijriyah. Pada abad ini, irfan dalam tradisi Sunni tidak mengalami perkembangan, bahkan justru mengalami kemunduran. Para tokohnya hanya cenderung memberikan komentar dan ikhtisar atas karya-karya terdahulu, dan lebih menekankan bentuk ritual dan formalisme, yang terkadang mendorong mereka menyimpang dari subtansi ajarannya sendiri. Meskipun demikian, irfan teoritis yang umumnya ada di kalangan Syi'ah dan bersatu dengan pemikiran filsafat tetap berkembang pesat. Di tanah air, irfan teoritis dikembangkan oleh beberapa tokoh, antara lain, Hamzah Fansuri (w.1590 M) dan Syamsuddin Sumatrani (w.1639 M), yang dikenal dengan "martabat tujuh" ${ }^{18}$

\section{Burhani}

Epistemologi burhani menyandarkan diri pada kekuatan rasio atau akal, yang ditempuh dengan dalil-dalil logika. Burhani dapat diartikan sebagai suatu aktivitas berpikir untuk menetapkan kebenaran proposisi (qadhiyah) melalui

\footnotetext{
${ }^{15}$ Atang Abdul Hakim dan Beni Ahmad Saebani, filsafat Umum: dari metodologi sampai Teofilosofi, (Bandung: Pustaka Setia, 2008) 472.

${ }^{16}$ Khudori Soleh, Filsafat Islam, 262

${ }^{17}$ Ibid, 260.

${ }^{18} \mathrm{Ibid}, 263$.
} 
pendekatan deduktif dengan mengaitkan prosisi yang satu dengan prosisi yang lain yang telah terbukti kebenarannya secara aksiomatik.

Epistemologi burhani lebih menekankan pada potensi bawaan manusia secara naluriyah. Jadi, epistemologi burhani adalah epistemologi yang berpandangan bahwa sumber ilmu pengetahuan adalah akal. Akal menurut epistemologi ini mempunyai kemampuan untuk menemukan berbagai pengetahuan, bahkan dalam bidang agama sekalipun akal mampu untuk mengetahuinya, seperti masalah baik dan buruk. Dalam bidang keagamaan, burhani banyak dipakai oleh aliran berpaham rasionalis, seperti mu'tazilah dan ulama-ulama mudarat. ${ }^{19}$

Senada dengan pendapat di atas, Ibn Bajjah menempatkan akal pada posisi yang sangat penting. Dengan perantara akal, manusia dapat mengetahui segala sesuatu, termasuk dalam mencapai kebahagiaan dan masalah Ilahiyat. Akal, menurut Ibn Bajjah terdiri dari dua jenis. Pertama, Akal Teoritis; yang diperoleh berdasarkan pemahaman terhadap sesuatu yang konkrit atau abstrak. Kedua, Akal Praktis; yang diperoleh melalui penyelidikan (eksperemen) sehingga menemukan ilmu pengetahuan. ${ }^{20}$

Menurut Al-Jabiri (1936-2010 M), prinsip-prinsip logis yang digunakan dalam burhani pertama di bangun oleh Aristoteles (384-322 M) dengan metode analitik (tahlili), yaitu suatu sistem berpikir yang didasarkan atas dasar tertentu dengan mengambil sepuluh kategori sebagai objek kajiannya, antara lain: kuantitas, kualitas, ruang, dan waktu. Sistem pemikiran Aristoteles ini kemudian pecah menjadi dua aliran, yaitu Iskandariyah dan Athenian. Madzhab Iskandariyah adalah aliran yang tetap konsisten dan berusaha menjadi filsafat Aristoteles secara murni. Sedangkan madzhab Athenian (Hellenisme) adalah aliran yang mencoba menggabungkan antara pemikiran Aristoteles dengan pemikiran lainnya, khususnya Plato (427-347 M) dan Plotinus (205-270 M) yang banyak mengajarkan filsafat neo-platonis.

Pada perkembangan selanjutnya, metode berpikir analitik Aristoteles masuk pada pemikiran Islam melalui program terjemahan buku-buku filsafat yang dilakukan pada masa Dinasti Abbasiyah (750-1258 M), yaitu pada masa Khalifah Al-Makmun (811-833 M), yang menurut Al-Jabiri sebagai awal sejarah pertemuan pemikiran epistemologi burhani Yunani dengan epistemologi bayani Arab.

Sarjana Islam pertama yang mengenalkan dan menggunakan metode burhani adalah Al-Kindi (806-875 M) dalam kitabnya al-Falsafat al-Ula, yang

19 Zainul Kamal, Ibn Taimiyah Versus Para Fiosof, 53.

20Sirajuddin Zar, Filsafat Islam Filosof dan Filsafatnya 195-196 


\section{Umi Kulsum}

Epistimologi Islam Dalam Tinjauan Filosofis

dipersembahkan untuk khalifah Al-Mu'tasim (833-842 M). Al-Kindi, telah berjasa memperkenalkan dan mewariskan persoalan-persoalan filsafat yang terus berkembang samapi saat ini, seperti, penciptaan semesta, keabadian jiwa, dan pengetahuan Tuhan. ${ }^{21}$

Metode rasional atau burhani kemudian semakin berkembang dan menjadi salah satu sistem pemikiran Arab Islam. Al-Razi (865-925 M), ia dikenal sebagai tokoh rasionalis murni yang menempatkannya sebagai dasar penalaran, bahkan satu-satunya pertimbangan kebenaran yang dapat diterima. Selanjutnya, posisi burhani dikuatkan oleh Al-Farabi (870-950 M). Filsuf yang mendapat gelar "Guru Kedua" al-Muta'allim al-Tsani setelah Aristoteles sebagai "Guru Pertama" al-Muta'allim al-Awwal, karena pengaruhnya yang besar dalam filsafat Islam setelah Aristoteles, maka burhani mendepatkan posisi sebagai metode paling baik dan unggul, sehingga ilmu filsafat yang memakai metode burhani dinilai lebih tinggi kedudukannya dibanding ilmu-ilmu agama, seperti ilmu kalam dan fiqh yang tidak mempergunakan metode burhani.

Pada perkembangan selanjutnya, prinsip metode burhani telah digunakan tidak hanya oleh kalangan filsuf, tetapi juga oleh para fuqaha seperti Al-Jahizh dan Al-Syatibi, juga kalangan sufi falsafi seperti Suhrawardi dan Ibn Arabi, bahkan juga digunakan oleh tokoh-tokoh yang menolak fisafat, seperti AlGhazali untuk memperkuat gagasan-gagasannya. ${ }^{22}$

\section{Implikasi Terhadap Epistemologi Islam}

Epistemologi atau teori ilmu pengetahuan adalah cabang filsafat yang membahas tentang hakikat, ruang lingkup dan batasan-batasannya. Teori mengenai hakikat pengetahuan ini ada dua macam. Pertama, Realisme. Menurut kaum realis, pengetahuan adalah gambaran yang sebenarnya dari objek yang diketahui. Kedua, Idealisme. Menurut aliran ini, pengetahuan adalah proses mental dari subjek yang mengetahui.

Masuknya logika Aristoteles ke Dunia Islam memacu perkenbangan epistemologi, karena terdapat hubungan antara pengetahuan samawi (wahyu) dan pengetahuan manusiawi, pengetahuan supernatural dan pengetahuan rasionalnatural, antaraiman dan akal. Dengan keanekaragaman pengetahuan ini muncul sebuah pertanyaan, pengetahuan manakah yang paling relevan dan berkualitas, melaui jalan iman atau ilmu, kepercayaan atau pembuktian?. Kalangan "beriman" di satu pihak menyatakan bahwa pengetahuan manusia yang dihasilkan oleh akal harus disempurnakan dengan pengetahuan adikodrati (wahyu); sedangkan

${ }^{21}$ Ibid; 34.

${ }^{22}$ Khudori Soleh, Filsafat Islam, 262 
kalangan intelektual berpendapat bahwa iman (wahyuhal-haladikodrati dan samawi) adalah omong kosong kalau tidak terbuktikan oleh akal. Oleh karena itu timbullah masalah wahyu dan akal. ${ }^{23}$

Kata akal berasal dari kata arabal-'aql yang dalam bentuk kata benda tidak terdapat dalam al-Quran; al-Quran hanya membawa bentuk kata kerjanya'aqaluhdal 1 ayat, ta'qilun 24 ayat, na'qil 1 ayat dan ya'qilun 22 ayat. Katakata itu dalam arti paham dan mengerti. Sedangkan wahyub erasal dari kata Arab alwahyberartisuara, api dan kecepatan juga mengandung arti bisikan, isyarat, tulisan, dan kitab. Tetapi kata itu lebih dikenal dengan arti apa yang disampaikan Tuhan kepada nabi. ${ }^{24}$

Situasi ini dalam Islam telah memberikan perhatian besar dalam masalah epistemologi, karena berusaha untuk menjalin perpaduan sistematik antara pengetahuan dan ajaran wahyu disatu pihak dengan pengetahuan dan ajaran manusiawi intelektual-rasional di lain pihak. Di dalam Islam telah terjadi pertemuan dan sekaligus juga pergumulanantaraakal dan wahyu. Terjadinyasublimasikalanganberiman di atas, kalangan intelektual Islam telah memberikan dampak yang melumpuhkan perkembangan akal dalam Islam. Sedangkan para filosof telah berusaha dan dapat mengharmoniskan pengetahuan akal manusiawi-rasional dengan ajaran agama yang bersifat samawi-supranatural. Namun, perpaduan tersebut selalu saja dilihat oleh kalangan beriman dengan sikap ketidakpercayaan dan kecurigaan. ${ }^{25}$

Terlepas dari pro dan kontra dari pertumbuhan dan perkembangan logika Aristoteles di dunia Islam, dengan sikap yang optimistis, ia telah memberikan dampak yang besar dalam melahirkan dan mengembangkan beberapa aliran epistemology dalam Islam. Ia dapat dinilai positif, dalam artian bahwa dengan secara tidak langsung logika Aristoteles yang bercirikan pemikiran rasional telah melahirkan suatu macam teologi kalangan rasionalis dalam Islam, yang diwakili oleh kalangan Mu'tazilah. Di dalam sejarah Islam, kaum Mu'tazilah pernah melahirkan khazanah intelektual yang sangat kental dengan keislaman, di samping itu, ditangan merekapulalah Islam pernah mencapai puncak keemasannya dalam melahirkan peradaban umat manusia, yang dimulai oleh alMa'mun dengan mendirikan sebuah wisma kearifan (Bait al-Hikam). Kelahiran

\footnotetext{
${ }^{23}$ Untuk memperoleh pengetahuan tentang ketuhanan dan kewajiban manusia terhadap Tuhan dalam ajaran Islam, manusia mempergunakan akal dan wahyu. Akal sebagia nugerah Tuhant erhadap manusia, mempunyai daya berpikir dan berusaha untuk sampai kepada Tuhan. Sedangkan wahyu yang dating dari Tuhan mengandung ajaran dan petujuk bagi manusia tentang Tuhan dan kewajiban-kewajiban manusiat erhadap-Nya. Afraniyati Affan, Sejarah Pemikiran Islam: Teologi Ilmu Kalam, (Jakarta: Amzah, 2012). 221.

${ }^{24}$ Ibid; 223-224

${ }^{25}$ Zainul Kamal, Ibn Taimiyah Versus Para Fiosof , 205.
} 


\section{Umi Kulsum}

Epistimologi Islam Dalam Tinjauan Filosofis

kaum rasionalis Islam Mu'tazilah, yang banyak memakai dan menjunjung tinggi akal tidak dapat dilepaskan dari pengaruh besar dalam pengunaan penalaran logislogika Aristoteles. ${ }^{26}$

Secara epistemologis, kebangkitan dunia Islam tidak dapat terlepas dari kesadaran dan kebangkitan umat Islam itu sendiri dalam mempergunakan pemikiran rasional semaksimal mungkin dengan teratur dan sistematis. Karena itu, menurut Muhammad Abduh, pemikiran rasional merupakan dasar utama dari ajaran Islam. Kata beliau, dengan berpikir rasional maka akan menuju jalan untuk memperoleh iman sejati. Iman tidaklah sempurna kalau tidak didasarkan pada akal. Dengan pemikiran rasionallah kita akan dapat melihat segala sesuatu secara kritis dan objektif. ${ }^{27}$.

\section{KESIMPULAN}

Epistemologi merupakan cabang dari disiplin ilmu filsafat mengenai pengetahuan yang membahas hakikat, ruang lingkup dan batasan-batasannya. Studi ini sebagai sarana dalam memecahkan suatu pertanyaan-pertanyaan mendasar. Dalam pemikiran islam, epistemologi mencakup tiga struktur, yaitu epistemologi bayani, epistemologi irfani, dan epistemologi burhani.

Epistemologi Bayani bisa juga diartikan sebagai pemikiran yang menekankan otoritas teks (nash), artinya memahami teks sebagai pengetahuan tanpa ada penafsiran. Secara termenologi, bayan mempunyai dua arti, yaitu sebagai aturan-aturan penafsiran wacana dan syarat-syarat memproduksi wacana.Epistemologi ini, dikembangkan dan digunakan oleh para fuqaha, mutakallimun dan ushuliyyun.

Epistemologi irfani merupakan salah satu model penalaran yang dikenal dalam tradisi keilmuan Islam, di samping bayani dan burhani. Epistemologi ini dikembangkan dan digunakan dalam masyarakat sufi. Irfan atau makrifat berkaitan dengan pengetahuan yang diperoleh secara langsung dari Tuhan (kasyf) lewat olah rohani yang dilakukan atas dasar cinta atau iradah atau kemauan yang kuat.

Sedangkan Epistemologi burhani menyandarkan diri pada kekuatan rasio atau akal, yang ditempuh dengan dalil-dalil logika. Epistemologi ini berpandangan bahwa akal sebagai sumber ilmu pengetahuan Akal menurut epistemologi ini mempunyai kemampuan untuk menemukan berbagai pengetahuan, bahkan dalam bidang agama sekalipun akal mampu untuk

26Ibid, 206.

27Ibid; 214. 
Umi Kulsum

Epistimologi Islam Dalam Tinjauan Filosofis

mengetahuinya, seperti masalah baik dan buruk. Dalam bidang keagamaan, burhani banyak dipakai oleh aliran berpaham rasionalis, seperti mu'tazilah dan ulama-ulama mudarat. 
Umi Kulsum

Epistimologi Islam Dalam Tinjauan Filosofis

\section{DAFTAR PUSTAKA}

Affan,Afraniyati. Sejarah Pemikiran Islam: TeologiIlmu Kalam, Jakarta: Amzah, 2012.

Abdul, Hakim Atang dan Beni Ahmad Saebani, filsafat Umum: dari metodologi sampai Teofilosofi, Bandung: Pustaka Setia, 2008.

Al-Jabiri, Bunyah Al-Aql Al-Arabi, beirut: al-markaz al-Tsaqafi al-Arabi, 1993

Kamal, Zainul. Ibn Taimiyah Versus Para Fiosof: Polemik Logika, Jakarta: Raja Grafindo Persada, 2006.

Soleh, Khudori. Filsafat Islam; dari Klasik hingga kontemporer, Jogjakarta: Arruzz Media, 2013

Zar, Sirajuddin. Filsafat Islam: filosof dan filsafatnya, Jakarta: Raja Grafido Persada, 2012. 